\title{
ALTERIDADE E IDENTIDADE EM MEU PEQUENO PAÍS, DE GAËL FAYE ${ }^{1}$
}

\author{
Leila Cristina de Melo Darin \\ Marina Ribeiro Candido
}

Sempre escrevemos a partir de uma ausência [...]

Sylvia Molloy

[...] ando perdido no mundo, na imensidão duma profunda madrugada.

Ondjaki

Resumo: A busca do Eu e o confronto com o Outro têm se tornado um tema cada vez mais presente nas obras literárias contemporâneas, o que justifica o interesse em refletir sobre questões relativas à alteridade e à identidade a partir da análise do livro Meu pequeno país (2018), do escritor burundiano Gaël Faye. A narrativa, com fortes indícios autobiográficos, sugere uma reescrita da história, uma tentativa de definir, partindo do que o narrador não é (o Outro), a sua própria identidade (um Eu fragmentado). Pretendemos demonstrar como se dá a retomada da infância e a rememoração desse espaço-tempo da felicidade. O apoio teórico conta com Hall (2005), Silva (2005), Brugioni (2019) e Dutra (2012).

Palavras chave: Literatura africana. Gäel Faye. Alteridade. Identidade.

Abstract: The search for the Self and the confrontation with the Other have become increasingly present in contemporary literary works. It is the aim of this paper to contribute to the discussion of the theme by examining issues of alterity and identity in the novel Small country (2018) by Burundian writer Gaël Faye. The narrative, containing strong autobiographical evidence, suggests a rewriting of the author's life story in an effort to define his own identity (a fragmented Self), by considering what he is not (the Other). We intend to demonstrate how the resumption of childhood experiences and the remembrance of this space-time of happiness occurs. The theoretical support is taken from Hall (2005), Silva (2005), Brugioni (2019) e Dutra (2012).

Keywords: African literature. Gäel Faye. Alterity. Identity.

1 Título em língua estrangeira: "Alterity and identity in small country, by Gaël Faye". 


\section{Considerações iniciais}

A questão do "outro" tem se tornado central nos estudos literários contemporâneos, e estudiosos como Janet $M$. Paterson (2007) e João Vianney Cavalcanti Nuto (2008) alertam para o fato de que atualmente vivemos em um mundo cada vez mais sensível a esse tema. As grandes ondas de imigração, iniciadas nos anos 1970, e a globalização impactaram diretamente a criação de um ambiente mais atento à outridade/alteridade, o que tem levado a considerações sobre a formação e manutenção de identidades.

O objetivo desta análise é refletir sobre a representação do Outro e a busca da identidade no livro Meu pequeno país (2018), de Gaël Faye. A obra foi publicada originalmente em francês, no ano de 2016, e traduzida para 29 línguas, vendendo mais de 800 mil cópias mundialmente, além de ter recebido o prêmio Goncourt des Lycéens. Escrita pelo rapper burundiense Gaël Faye, cujo pai é francês e a mãe é ruandesa, a obra surgiu por sugestão de um editor literário que tomou conhecimento do talento para a escrita de Faye ao ouvir as músicas compostas por ele. Nascido em 1982, Faye mudou-se para França no ano de 1995, por causa da guerra civil e do genocídio que ocorreram em Ruanda.

Em Meu pequeno país, o narrador-personagem Gabriel retoma sua infância e narra seu cotidiano em casa, na escola 
e nas brincadeiras de rua em sua terra natal, o Burundi. O cerne da narrativa são os conflitos étnicos e como eles destruíram o país onde ele nasceu, roubaram sua infância e dividiram sua família - de pai francês branco e mãe ruandesa negra. Apesar da similaridade entre a vida do autor e a de seu narrador-personagem, Gaël Faye afirma que o livro não é autobiográfico: "Para escrever algo autobiográfico prefiro fazer uma música. Fora que fazer livro de memórias é o melhor jeito de ter problemas com a família" (FAYE apud MEIRELES, 2019). Mas o diálogo entre sua obra, sua história pessoal e a história de seu país é bastante evidente, o que indica que sua ficção emerge - até certo ponto - de uma experiência pessoal.

\section{Um pouco de história}

O Burundi é um pequeno país da África Central, cuja capital é Bujumbura, que faz fronteira com a Ruanda, a Tanzânia e o Congo. A estimativa da população, em 2015, era de 10.813.000 habitantes. As línguas oficiais do país são o rundi, que faz parte das línguas bantu, e o francês, devido ao domínio belga que ocorreu na região depois da Primeira Guerra Mundial.

O país tem duas principais comunidades étnicas: os hútus e os tútsis ${ }^{2}$. Os primeiros representam mais de $80 \%$

2 A grafia dos termos hútu e tútsi variam entre acentuado e não acentuado. Neste artigo, 
da população do país; já os tútsis representam pouco mais de $15 \%$ da população. Contudo, os primeiros habitantes da região que hoje forma o Burundi, provavelmente foram os pigmeus tuás, que nos dias de hoje representam apenas cerca de $1 \%$ da população. Acredita-se que os hútus se estabeleceram na região no século XI. Cerca de trezentos ou quatrocentos anos depois, chegaram os tútsis, que estabeleceram uma monarquia e assumiram o controle da região a partir do século XVI.

Até o século XIX, os principais reinos da região dos Grandes Lagos na África central - Buganda, Bunyoro, Ankole, Karagwe, Ruanda e Burundi - haviam se mantido praticamente isolados do mundo exterior. Ao longo de três séculos, eles tinham evoluído de sociedade clânica e se amalgamado em monarquias sofisticadas no controle de porções consideráveis tanto de território quanto de densidade populacional, sem auxílio de dinheiro ou escrita. [...] Nos reinos de montanhas de Ruanda, Burundi e Ankole, o gado era a espinha dorsal de suas economias. A elite no poder em Ruanda e no Burundi era formada por tútsis proprietários de gado que governavam como uma aristocracia pastoril, coletando tributo da maioria da população de agricultores hutus. (MEREDITH, 2017, p. 304)

Até esse período, a identificação como tútsi ou hútu era fluida; apesar das características físicas serem, 
informalmente, utilizadas na identificação, o conceito não era fechado. A divisão social residia no fato de os tútsis serem tradicionalmente proprietários de gado, o que naquela sociedade indicava status e riqueza, enquanto os hútus eram tradicionalmente agricultores, o que não indicava uma posição privilegiada. No entanto, segundo Martin Meredith, "hutus e tútsis moviam-se igualmente de um grupo para o outro. [...] Gerações de casamentos mistos, migração e mudança ocupacional tinham obscurecido a distinção" (MEREDITH, 2017, p. 523).

Foi na segunda metade do século XIX que a Alemanha e, depois, a Bélgica dominaram a região. A chegada dos colonizadores ajudou a acentuar os problemas étnicos que existiam, pois os europeus presumiram que as etnias poderiam ser facilmente identificadas a partir das características físicas e criaram um sistema de classificação em que a identidade deixou de ser fluida e tornou-se fechada e excludente.

No início da década de 1900, no entanto, as autoridades alemãs identificaram hutus e tútsis como grupos étnicos distintos. Com poucos funcionários próprios no local, eles confiaram nos tútsis, como a aristocracia dominante, para impor controle, permitindoIhes aumentar sua hegemonia sobre os hutus. Os belgas foram mais longe. Na década de 1920, eles introduziram um sistema de 
cartões de identificação, especificando a tribo que o titular pertencia. Os cartões impossibilitaram que hutus se tornassem tútsis. [...] Ao final dos anos 1930, os belgas fizeram da identidade tribal a característica definidora da vida comum tanto em Ruanda quanto no Burundi. (MEREDITH, 2017, p. 304)

Devido a sua pele geralmente mais clara e a sua maior estatura e à tendência europeia para essas características físicas, os tútsis foram considerados superiores aos hútus e foram privilegiados com postos na administração local. Essa classificação ajudou a perpetuar o poder que já estava concentrado nas mãos da minoria tútsi.

O Burundi tornou-se independente em 1962, mas os conflitos internos apenas se intensificaram. Ainda que o genocídio ocorrido no país vizinho, Ruanda, tenha recebido mais atenção mundial e seja mais lembrado, o Burundi também foi profundamente afetado pelos conflitos étnicos e perdeu centenas e centenas de vidas entre os anos de 1993 e $2005^{3}$, além dos milhares de burundienses que se refugiaram em países vizinhos. Ainda hoje os reflexos dessas disputas são sentidos no país africano, que continua a viver

3 Conforme relata o jornal português Mundo ao minuto, em janeiro de 2020, a Comissão para a Verdade e Reconciliação do Burundi revelou que mais de 4.100 valas comuns foram descobertas e 142.505 corpos encontrados. Disponível em: https://www.noticiasaominuto. com/mundo/1393753/mais-de-4100-valas-e-142505-corpos-descobertos-no-burundi. Acesso em: 6 abr. 2021. 
em instabilidade política e social.

\section{O Eu e o Outro}

A contextualização sobre a história do Burundi, apesar de breve, é necessária para compreender como se dá a representação do Outro e a busca pela identidade na obra de Gaël Faye.

A representação do Outro tem início no próprio autor, já que Gaël Faye é, ele mesmo, fruto de duas culturas. Apesar de viver na França desde a infância, o autor compartilhou em entrevistas que a cor de sua pele sempre levanta dúvidas sobre sua origem, uma vez que ele é mestiço. Sua identidade é dividida em - pelo menos - duas culturas, duas realidades, duas vivências que se querem, ou se construíram, opostas. Isso resulta em certa indeterminação do eu-autor que narra e se reflete na dificuldade que seu narrador-personagem, Gabriel, tem para definir seu pertencimento.

Em sua obra, observamos que a alteridade é representada por meio de metáforas, referidas como "da outra raça", "do outro gênero", "da outra idade" e "do outro país". Porém, a figura de alteridade que mais se evidencia ao longo da narrativa é a "outra etnia"; isso se revela nos embates entre hútus e tutsis que permeiam todo o romance e são o mote 
da história. Gabriel compartilha com os leitores os embates entre a visão do pai europeu e da mãe ruandesa exilada no Burundi. Podemos perceber que essa oposição vai ter um impacto direto na construção da identidade do menino.

Já no prólogo da obra, o narrador compartilha com o leitor a explicação que recebeu do pai a respeito dos conflitos de seu país. Michel, o pai, cidadão francês, expõe um modo de enxergar a questão étnica no Burundi que é um bom exemplo de como o pensamento europeu ajudou a aprofundar as disputas de poder no pequeno país africano.

Não sei bem ao certo como esta história começou.

Papai, no entanto, um dia nos explicou tudo na caminhonete.

- Prestem atenção, no Burundi é como em Ruanda. Há três grupos diferentes, chamados etnias. Os hútus são os mais numerosos: são baixinhos e têm o nariz grosso.

[...] E tem também os pigmeus. Mas vamos deixar esses de lado, porque são tão poucos que nem contam. E tem os tútsis, como sua mãe. Os tútsis são menos numerosos que os hútus, altos, magros e com o nariz fino, e nunca se sabe o que lhes passa pela cabeça. Você, Gabriel - dissera ele me apontando o dedo -, é um verdadeiro tútsi, nunca se sabe no que você está pensando.

Então, perguntei:

- A guerra entre os tútsis e os hútus é por que eles não têm o mesmo território?

- Não, não é isso, eles vivem no mesmo país. 
- Então... é por que não têm a mesma língua?

- Não, eles falam a mesma língua.

- Então é por que não têm o mesmo deus?

- Não, eles têm o mesmo deus.

- Então... por que estão em guerra?

- Porque não têm o mesmo nariz. (FAYE, 2018, p. 7-8)

Diante dessa resposta categórica e de difícil compreensão para o menino, prossegue o narrador, na voz de Gabriel:

[...] Desse dia em diante, eu e minha irmãzinha, Ana, tentávamos discretamente adivinhar quem era hútu e quem era tútsi. Cochichávamos:

- Aquele ali de calça branca é um hútu: é baixinho e tem nariz grosso.

- É, e aquele gigante lá de chapéu, muito magro e de nariz bem fino é tútsi.

- E aquele lá de camisa listrada é um hútu.

- Não é, não. Olhe bem, ele é alto e magro!

-É, mas tem nariz grosso!

Foi aí que começamos a desconfiar dessa história de etnias. Além do mais, Papai não queria que tocássemos mais no assunto. Para ele, as crianças não deviam se meter em política. (FAYE, 2018, p. 8)

Este trecho é importante para analisarmos como, logo no início da narrativa, o narrador nos mostra que as questões étnicas são parte do cotidiano do Burundi, a ponto de ser um assunto que chama a atenção até mesmo das crianças. Ao mesmo tempo, percebe-se como Michel trata a questão de forma superficial e estreita, retomando as características 
físicas como forma de classificar seres humanos e ajudando a perpetuar um pensamento preconceituoso que se encontra na raiz dos conflitos sociais do Burundi. Poderíamos considerar que a simplificação da questão leva em conta seus interlocutores, pois se trata de uma conversa com seus filhos; porém, simplificar não significa banalizar, e a resposta do pai sinaliza que é fundamental refletir sobre posições que pressupõem que crianças são intelectualmente imaturas para entender a profundidade e as consequências do convívio com as diferenças étnicas.

Contudo, em outros momentos de sua narrativa, o narrador-personagem retoma lembranças que mostram que a primeira impressão que temos do discurso de Michel é verdadeira - afinal, ele é um dos propagadores e mantenedores da ideia de supremacia do homem branco europeu, o que se reflete repetidamente em seu discurso.

- Do que você está reclamando, Michel? Por acaso come mal em casa? - perguntou Mamãe sem ternura.

- Claro! Aquele idiota do Prothé me obriga a engolir seus farináceos africanos todo dia no almoço. Se ao menos ele soubesse fazer direito um contrafilé!

- Nem me fale, Michel! - emendou Jacques.

- O macaco que trabalha na minha cozinha queima tudo sob o pretexto de matar os parasitas. Não sei mais o que é um bom bife com sangue. Não vejo a hora de voltar a 
Bruxelas e me empanturrar de amebas! Gargalhada geral. Apenas Ana e eu ficamos em silêncio, na ponta da mesa. Eu tinha dez anos e ela, sete. Talvez por isso nos escapasse o senso de humor de Jacques. De qualquer modo, havíamos sido proibidos de falar, a menos que se dirigissem a nós. Era a regra de ouro a ser cumprida quando éramos convidados a algum lugar. [...] Sobretudo na casa de Jacques, que era como um segundo pai para ele, um modelo, a ponto de repetir, sem mesmo se dar conta suas expressões, seus gestos e até mesmo suas inflexões de voz. 'Foi ele que me ensinou tudo sobre a África', repetia com frequência para Mamãe. (FAYE, 2018, p. 18)

Michel, bem como seu amigo Jacques, também francês, demonstram seu desprezo pelo povo e pelos costumes dos países em que vivem, Burundi e Zaire - atual República do Congo. Termos como "idiota" e "macaco" são usados para se referir aos homens que trabalham em suas casas, evidenciando uma atitude de desrespeito e desprezo. Importante também notar que Jacques é um modelo para Michel, pois foi ele que ensinou tudo que Michel conhece a respeito da África. Novamente, esse tipo de afirmação de Michel mostra como ele desconhece as histórias das nações do continente africano, e, mesmo vivendo no Burundi e tendo como mentor um homem que vive no Zaire, acredita que o que sabe se aplica ao vasto continente, pois considera 
que os homens da África são todos iguais. Ao refletir sobre os estereótipos, Elena Brugioni aponta que o de origem colonial é "pautado pela ideologia de que o ser humano negro não é um sujeito individual, mas sim um elemento indistinto de uma massa populacional alheia à humanidade ocidental - o outro" (BRUGIONI, 2019, p. 122).

Relevante para refletir sobre o que está na base daquilo que exclui um grupo e o rotula como um Outro, é a fala da estudiosa canadense Janet Paterson (2007), em entrevista a Sandra Almeida, a respeito da distinção entre diferença e alteridade:

A diferença é inerente aos nossos processos cognitivos, pois nos permite distinguir entre dia e noite, guerra e paz, baixo e alto e quente e frio. Há muitos contextos nos quais uma pessoa é diferente da norma (raça, gênero, religião, identidade sexual, características físicas, etc.) Porém, como explica Landowski, o que está em jogo não é a diferença. Ou seja, é a atribuição de características (ou marcas) semânticas à diferença que produz a alteridade [...] é o valor atribuído a essa diferença que produz a alteridade. [...] É desnecessário dizer que essa construção é arbitrária e reflete a ideologia e o desejo de poder de um grupo dominante. (PATERSON apud ALMEIDA, 2007, p. 16)

O que é preciso avaliar ao se considerar a alteridade - a forma como o Outro é definido e construído - não são as 
diferenças em si, mas o valor que se dá a elas, pois vale lembrar que o processo de significação se dá no interior da língua e das estruturas de poder que elaboram e reforçam juízos de valor. Kathryn Woodward (2005), ao ponderar sobre como a diferença é marcada em relação à identidade, também assinala o papel dos sistemas simbólicos de representação na criação de formas de exclusão social:

Um sistema classificatório aplica um princípio de diferença a uma população de uma forma tal que seja capaz de dividila (e a todas as suas características) em ao menos dois grupos opostos - nós/eles (por exemplo, servos e croatas); eu/outro. (WOODWARD, 2005, p. 40)

O sistema de classificação implantado pelos europeus no Burundi, e em outras colônias, é pautado na imposição do valor de superioridade/inferioridade, na construção da ideia de que entre as etnias há os mais aceitáveis e os menos aceitáveis. O teórico cultural e sociólogo britânicojamaicano Stuart Hall (2005) chama atenção para o processo de normalização que decorre da hierarquização das diferenças e das identidades:

Normalizar significa eleger - arbitrariamente - uma identidade específica como o parâmetro em relação ao qual as outras identidades são avaliadas e hierarquizadas. Normalizar significa atribuir a essa 
identidade todas as características possíveis, em relação às quais as outras identidades só podem ser avaliadas de forma negativa. (HALL, 2005, p. 83)

Entre africanos e europeus, no território burundiense, o enaltecimento de tudo que é europeu impõe à sociedade uma "verdade" - a de que é o europeu o padrão a ser seguido, como podemos observar no trecho do romance, a seguir:

- Deixe Deus em paz no canto dele, por favor! - retorquiu Jacques. - Ainda bem que restam alguns brancos no Zaire, para manter a roda girando. Se não fosse eu, você estaria mendigando como os outros da sua espécie! - Quando falo de Deus, falo de você, patrão! - replicou o cozinheiro com malícia.

- Não deboche da minha cara, macaco! (FAYE, 2018, p. 19-20)

Podemos relacionar a maneira como o personagem francês Michel caracteriza os tútsis ao pensamento da filósofa Maria Manuel Baptista: “o Outro é pensado como realmente diferente e incompreensível, irredutível à nossa visão do mundo, e em última análise, irracional, porque imprevisível segundo a nossa própria lógica" (BAPTISTA, 2007, p. 289). Para Michel, esse grupo étnico é como um Outro, que não age segundo o que ele - Michel - acha correto; por isso, é um Outro imprevisível e perigoso. O Outro que 
não pode ser completamente entendido, por isso é temido e deve ser controlado e submetido - em última instância, exterminado. Paterson nos lembra que "a alteridade está na raiz das guerras, do racismo e da discriminação" (PATERSON apud ALMEIDA, 2007, p. 15). Faye, por meio de seu trabalho artístico com a palavra, cria uma representação ficcional que traduz esse pensamento.

Podemos ainda observar no discurso do personagem Michel sobre o Burundi que ele enxerga a África pelo viés do exotismo, mas também como um lugar em que sua posição é incontestavelmente superior, já que ele representa o modelo europeu. Como Nuto bem observa, “o sintagma 'o outro' revela, em si, tensões políticas e ideológicas, trazendo implícita uma noção vaga, transmitida por senso comum do que seja 'o mesmo': o homem 'branco', 'ocidental', letrado, heterossexual e, em geral, de classe média ou alta" (NUTO, 2008, p. 183).

Esse é o padrão que Michel representa, o de um privilegiado, o que o coloca no centro da sociedade burundiense, mesmo em um cenário pós-colonial, como é o caso do Burundi nos anos 1990. Mas, se no Burundi ele goza de um status de superioridade, na França ele seria mais um, ou nas palavras do próprio personagem: ninguém. 
- Escute, querida - disse papai em tom conciliador. - Olhe ao redor. Essas montanhas, esses lagos, essa natureza. Moramos em casas bonitas, temos empregados, espaço para as crianças, um clima bom, os negócios andam bem. O que você quer além disso? Você nunca terá todo esse luxo na Europa. Acredite em mim, está bem longe de ser o paraíso que imagina! Por que acha que construí minha vida aqui já faz vinte anos? [...] Aqui, somos privilegiados. Lá não seríamos ninguém. (FAYE, 2018, p. 22)

Nosso narrador-personagem não apresenta apenas a visão do pai europeu a respeito do seu país, ele também insere em sua narrativa a visão da mãe, Yvonne, que como vimos, é natural de Ruanda, mas vive exilada no Burundi. Yvonne não pensa a África como um refúgio paradisíaco, pois sua condição de mulher negra e tútsi faz com que, para ela, o sonho de refúgio seja a Europa.

Você fala, fala, mas eu conheço o outro lado da moeda aqui. Onde você vê a suavidade das colinas, eu conheço a miséria de seus habitantes. Enquanto você se encanta com a beleza dos lagos, eu já respiro o metano que está no fundo das águas. Você fugiu da tranquilidade de sua França em busca de aventuras na África. Bom para você! Eu procuro a segurança que nunca tive, o conforto de criar meus filhos num país onde não temos medo de morrer pelo que somos [...]. (FAYE, 2018, p. 22) 
Em seu discurso, Yvonne mostra que tem uma imagem idealizada da Europa como um lugar onde poderá viver em paz, sem se sentir ameaçada por pertencer à sua etnia. Sem dúvida, a expectativa de que a Europa seja um território promissor persiste até os dias de hoje no imaginário de muitos - haja vista as grandes ondas de imigração de pessoas que buscam refúgio devido a conflitos e guerras ou o número de pessoas que procuram retorno financeiro e oportunidades de emprego. Em outros momentos da narrativa, Yvonne externa seu desconforto e descontentamento em viver no Burundi.

- É o que canso de repetir ao Michel - disse Mamãe. - Eu também não aguento mais aquele país.

- Para você, é diferente, Yvonne - retorquiu Papai, irritado. Seu sonho é viver em Paris, virou uma obsessão.

- Sim, seria bom para você, para mim, para as crianças. Qual é o nosso futuro em Bujumbura, além dessa vidinha miserável? Pode me dizer?

- Não comece, Yvonne! Você está falando do seu país.

- Não, não e não... Meu país é Ruanda! Ali, na sua frente. Ruanda. Sou uma refugiada, Michel. É o que sempre fui aos olhos dos burundienses e sempre me deixaram isso bem claro com seus insultos, suas insinuações, suas cotas para estrangeiros e suas vagas limitadas na escola. (FAYE, 2018, p. 22) 
Fica claro que o desprezo de Yvonne pelos burundienses é oriundo do tratamento que eles dispensam a ela como ruandesa exilada; para os burundienses, ela representa o Outro, o que nos leva a lembrar e a refletir sobre que tipo de Outro somos hoje para aqueles que nos rodeiam.

\section{Perdido no mundo}

É importante, nas considerações que tecemos aqui, chamar a atenção para o uso do narrador-criança nas literaturas africanas. Nelas, tal recurso não é novo e autores como J. M. Coetzee, Luandino Vieira, Manuel Rui e Ondjaki - assim como Faye - criaram obras em que a infância ocupa lugar central.

Segundo Robson Dutra, na produção literária africana "a temática infantil é abordada por autores em diversas épocas e espaços" (DUTRA, 2012, p. 230). Por meio da representação da infância é possível acessar uma forma de compreender determinada época por meio de memórias e imagens. Brugioni pontua que ao observar as obras de autores das literaturas africanas,

[...] vemos que a infância desempenha uma função matricial no que concerne a um conjunto de problematizações críticas que se prendem, por exemplo, à narração da nação pós-colonial, chamando a atenção para categorias críticas específicas, tais como o 
Bildungsroman e o romance de formação, e instituindo a infância como a fase mais significativa da vida humana [...]. Àsemelhança do contexto europeu, a emergência do romance de formação africano, parece surgir correspondendo a momentos e situações de grandes transformações políticas, sociais e culturais em que indefinição que caracteriza a transição é reconduzível às transformações determinadas pela 'situação colonial'. (BRUGIONI, 2019, p. 123-124, grifos do autor)

Para Dutra, o Bildungsroman é "centrado no processo de desenvolvimento interior do protagonista, evidenciando o conflito entre o 'Eu' e o mundo" (DUTRA, 2012, p. 231). Tal processo é observável em Gabriel que, à revelia dos esforços paternos, é continuamente confrontado com as demandas e indagações de um mundo incompreensivelmente desigual. Retomando Brugioni:

Dentro de um corpus, sem dúvida, vasto e diferenciado, produzido por autores de origens e tradições culturais e literárias diversas, o gênero romance de formação nas literaturas africanas contemporâneas parece ilustrar, por meio da infância, os desafios colocados pela pós-colonialidade, em que a intersecção entre histórias públicas [História] e privadas [memórias] se configura como uma estratégia narrativa e de representação crucial para (re)pensar o 'futuro do passado'. (BRUGIONI, 2019, p. 124, grifos do autor)

Apesar dos esforços de Michel para manter Gabriel e sua 
irmã, Ana, apartados das discussões políticas, é impossível ao garoto não observar as mudanças que ocorrem no seu dia a dia devido à instabilidade do país. Dentro da escola, a tensão entre os alunos é crescente e o discurso de ódio, disseminado dentro das casas e pelas ruas, é reproduzido no espaço da infância, o que nos permite observar, no tecido da obra literária de Faye, a intersecção entre História e memória.

Por mais que eu tente, não me lembro do instante em que começamos a pensar de modo diferente. A considerar que a partir de então, éramos nós de um lado e, do outro, inimigos como Francis. Por mais que eu revire minhas lembranças do avesso, não consigo me lembrar com clareza do instante em que decidimos não mais nos contentar em dividir o pouco que tínhamos e deixamos de confiar, passando a ver o outro como um perigo, a criar essa fronteira invisível com o mundo exterior, fazendo de nosso bairro uma fortaleza e, de nossa rua sem saída, um reduto. Ainda me pergunto quando eu e meus amigos começamos a ter medo. (FAYE, 2018, p. 69)

Ao analisarmos o texto literário, podemos observar que a macro esfera - os conflitos políticos e sociais - reflete-se na microesfera, ou seja, dentro da comunidade escolar e na vizinhança: ao mesmo tempo que o país se torna mais fechado e as liberdades são restringidas, os meninos passam a se recolher em seu bairro e em sua rua.

A ideia do outro como inimigo começa a encontrar 
espaço na mente de Gabriel e seus amigos, criando um ambiente de medo.

Até aquele dia, no recreio, quando dois meninos burundienses se atracaram atrás do pátio grande, longe do olhar dos professores e dos inspetores. Os outros alunos burundienses, inflamados com a altercação, logo se separaram em dois grupos, cada um apoiando um dos meninos. "Hútus imundos", diziam uns, "tútsis imundos", replicavam os outros. [...] Descobri o antagonismo entre hútus e tútsis, a linha de demarcação instransponível que obrigava cada um a ficar num ou noutro campo. [...] Hutu ou tútsi. Ou um ou outro. Cara ou coroa. [...] A guerra, sem que se peça, sempre se encarrega de encontrar um inimigo. Eu que desejava permanecer neutro, não pude. Tinha nascido com essa história. Ela corria em mim. Eu pertencia a ela. (FAYE, 2018, p. 115-116)

Importante notar que Gabriel define os meninos como burundienses, isto é, o narrador-personagem ainda não consegue entender como a tensão entre tútsis e hútus afeta sua a vida. Mas o antagonismo do Eu e do Outro tornase cada vez mais presente. Acostumado a viver em uma espécie de idílio, em que tem liberdade para ser criança, aos poucos, Gabriel se dá conta da crescente tensão política e étnica em seus país. As ideias de linha intransponível, de lados opostos e de divisão são cada vez mais frequentes na fala do menino e de seus amigos. Gabriel é confrontado com 
a existência do outro/da diferença e, consequentemente, começa a indagar quem ele é.

Quando eu propunha uma pescaria, dar uma pelo rio ou colher mangas, os colegas me mandavam passear - isso se tornara brincadeira de criança, tínhamos passado dessa idade.

[...]

- Nós vamos ser a gangue de Kinanira - concluiu Francis [...]. - Vou explicar como funciona. As gangues são armadas, estruturadas, têm hierarquia. Elas controlam as barreiras durante os dias de cidade morta. Todo mundo respeita as gangues. Nem os militares se metem com elas.

[...]

- Eu não quero ter nada a ver com esses assassinos - falei. A única coisa que eles sabem fazer é matar pobres criados que voltam do trabalho.

- Eles matam hútus, Gaby, e os hútus nos matam! - respondeu Gino. [...]

Eu queria dizer a Gino que ele estava enganado, que estava generalizando, que, se a gente se vingasse sempre, a guerra não teria fim [...].

- Gino tem razão. Na guerra, ninguém pode ser neutro! - disse Francis [...].

- E se a gente não quiser escolher um lado?

- perguntei.

- Não temos escolha, todos nós temos um lado - disse Gino [...]. (FAYE, 2018, p. 145-147)

Gabriel insiste em permanecer na infância e manter os velhos costumes, mas seus amigos já foram tomados 
pelo clima beligerante do país. O menino tenta entender o que está vivendo, mas insiste em ser neutro, não escolher lados. Sua atitude é vacilante, pois entende que os tútsis estão matando hútus (em sua experiência, os mortos são apenas pobres trabalhadores), e não deseja ser identificado ou relacionado a eles, mas ao mesmo tempo sofre por compreender que as famílias de seus amigos e sua própria família foram mortas por hútus.

Todas as rupturas, embates e transformações políticas colocam em crise a identidade do menino. Por todos os lados ele é classificado e discriminado, e, em alguns momentos, vê-se diante de situações em que lhe custa assumir uma posição, como fica claro nos seguintes trechos:

Mamãe retrucava que seus filhos eram francesinhos, que não deviam nos aborrecer com essas histórias dos ruandeses. [...] Vovó se ressentia por Mamãe não conversar com os filhos em kinyarwanda e dizia que essa língua nos permitiria manter nossa identidade no exílio. [...] Mamãe não dava a mínima para esses argumentos - para ela, éramos brancos com pele ligeiramente cor de caramelo, mas de qualquer maneira, brancos. Quando por acaso, dizíamos algumas palavras em kinyarwanda, logo debochava de nosso sotaque. $E$, em meio a tudo isso, eu digo a vocês que pouco me lixava para Ruanda. (FAYE, 2018, p. 59)

Ele era metade ruandês como eu, mas 
eu o invejava em segredo porque ele falava kinyarwanda com perfeição e sabia exatamente quem era. [...]

Quando estávamos os dois juntos, ele insistia que eu devia adquirir o que chamava de "identidade". Segundo ele, havia uma maneira de ser, de sentir e de pensar que eu devia ter. Usava as mesmas palavras de Mamãe [...] e repetia que ali não passávamos de refugiados, que precisávamos voltar para casa, para Ruanda.

Minha casa? Minha casa era ali. Verdade, eu era filho de uma ruandesa, mas minha realidade era o Burundi, a escola francesa, Kinanira, a rua sem saída. O resto não existia. (FAYE, 2018, p. 71)

Para o pai, Michel, ele é como um tútsi; para a mãe, Yvonne, um francesinho/branco; para os amigos, ele deve tomar uma posição como exilado, como ruandês tútsi que anseia voltar para casa; já sua avó quer que ele aprenda a língua de Ruanda para manter a identidade. O resultado é que o narrador-personagem, Gabriel, não sabe definir quem ele é. Inveja seus amigos que sabem bem quem são, mas não se identifica nem como hútu, nem como tútsi, nem como francês, pois todas essas realidades fazem parte integrante da sua vida.

Silva argumenta que "a afirmação da identidade e a marcação da diferença implicam, sempre, as operações de incluir e de excluir [...] dizer 'o que somos' significa também 
dizer 'o que não somos'” (SILVA, 2005, p. 82). Porém, na obra Meu pequeno país, o menino Gabriel toma o caminho contrário, começa por definir o que ele não é: "Não sou nem hútu nem tútsi - respondi. - Não tenho nada a ver com essa história. Vocês são meus amigos porque eu gosto de vocês e não porque são dessa ou daquela etnia" (FAYE, 2018, p. 160).

Ao afirmar que não é nem hútu nem tútsi, Gabriel se coloca como habitante do entrelugar, do espaço entre duas culturas; sua origem mestiça é que cria essa identidade fluida que não pode ser definida dentro de um sistema binário. A realidade em que ele vive o força a escolher um dos lados: identificar-se como tútsi ou como hútu, mas ele se nega a isso. Então, questiona o sistema de classificação das identidades vigente em seu país, implicitamente denunciando uma visão redutora e maniqueísta de realidade. Ao refletir sobre as questões identitárias na contemporaneidade, Tomás Tadeu da Silva (2005) destaca o conceito de hibridização como fundamental para a revisão dessas questões:

$\mathrm{Na}$ perspectiva da teoria cultural contemporânea, o hibridismo - a mistura, a conjunção, o intercurso entre diferentes nacionalidades, entre diferentes etnias, entre diferentes raças - coloca em xeque aqueles processos que tendem a conceber as identidades como fundamentalmente 
separadas, divididas, segregadas. O processo de hibridização confunde a suposta pureza e insolubilidade dos grupos que se reúnem sob as diferentes identidades nacionais, raciais ou étnicas. A identidade que se forma por meio do hibridismo não é mais integralmente nenhuma das identidades originais, embora guarde traços delas. (SILVA, 2005, p. 72-73)

Mais tarde, já adulto, nosso narrador-personagem, vivendo exilado na França, ainda não é capaz de dizer quem ele é, sendo essa indeterminação a doença de sua alma. Ele oscila entre os dois mundos que definiram sua infância, vive obcecado com o regresso, sem se sentir que pertence ao mundo europeu, mas ao mesmo tempo ciente de que voltar para o Burundi tampouco o fará se sentir em casa. Poeticamente, o narrador tenta explicar seu povo: "Vivíamos no eixo da grande fenda no exato lugar em que a África se fratura. Os homens desta região eram parecidos com esta terra." (FAYE, 2018, p. 100). Gabriel, assim como sua terra, o Burundi, vive fraturado. Esse sentimento encontra eco nas palavras de Zygmunt Bauman sobre a instabilidade das certezas no mundo contemporâneo: "Num ambiente de vida líquido-moderno, as identidades talvez sejam as encarnações mais comuns, mais aguçadas, mais profundamente sentidas e perturbadoras da ambivalência" (BAUMAN, 2005, p. 38).

\section{Considerações finais}


Em seu livro Quantas madrugadas tem a noite (2010), Ondjaki, importante autor da literatura angolana contemporânea, usa a imagem da madrugada para definir o entrelugar e a indeterminação identitária tão presente em suas obras literárias. A imagem da madrugada carrega em si a ambivalência do contemporâneo, funde em si a noite e o dia, pois se anuncia uma nova manhã, traz consigo a escuridão da noite anterior, configurando ao mesmo tempo um espaço de potência e possibilidades, mas também de mistério, solidão e até mesmo perigo.

Tecendo uma reflexão sobre nosso mundo policultural, marcado pelo deslocamento e pela diversidade, Bauman argumenta:

Tornamo-nos conscientes de que o 'pertencimento' e a 'identidade' não têm a solidez de uma rocha, não são garantidos para toda a vida, são bastante negociáveis e revogáveis, e de que as decisões que o próprio individuo toma, os caminhos que percorre, a maneira como age [...] são fatores crucias tanto para o 'pertencimento' como para a 'identidade'. (BAUMAN 2005, p. 16)

Se, conforme constatamos, a identidade hoje atravessa um contínuo processo de negociação e construção, não faz sentido pautar critérios e fronteiras demarcadas para ela. É dessa condição que nos fala Gaël Faye em Meu pequeno 
país, por meio dos conflitos e da perplexidade vivenciados pelo narrador-personagem.

Estudos sobre a alteridade e a identidade mostram-se necessários e mesmo urgentes e, nesse sentido, a literatura tem assumido seu papel, na voz de escritores das literaturas africanas como Gaël Faye, Ondjaki e Chimamanda Adichie, cujas narrativas ficcionais se alimentam dessas inquietações para resgatar memórias e reencenar histórias. Esses escritores desempenham um papel importante não apenas na busca pela identidade, mas também na recuperação do passado de seus países. Como Dutra aponta, "ao fazer dialogar com a ficção e história [...] recontam e conservam a história de seus países" (DUTRA, 2012, p. 240).

Jonatan Silva, a respeito Meu pequeno país, faz um comentário que endossamos: "Gaël Faye transforma a dor de uma nação em obra de arte, um espólio pela e para a paz entre os diferentes e os divergentes para que o exílio não seja mais que um elemento histórico" (SILVA, 2019, s.p.).

A literatura, ao recriar de modo crítico e criativo o mundo que vemos e que ajudamos a construir, oferece a valiosa possibilidade de refletir sobre as incertezas e as ambiguidades. Ela nos ajuda a compreender que também há beleza em partilhar narrativas complexas, sutis e sem final conhecido - 
onde se vive perdido em uma profunda madrugada.

\section{Referências}

ALMEIDA, Sandra. Entrevista concedida por Janet M. Paterson. Pensando o conceito de alteridade hoje. Tradução de Alcione da Cunha Silveira. Aletria, Belo Horizonte, v. 16, p. 13-19, julho/dezembro de 2007. BAPTISTA, Maria Manuel. Identidade e cultura: a questão do discurso sobre o outro. In: ROQUE-FARIA, Helenice; DIAS, Maria Prata de Lima (Orgs.). Cultura e identidade: discursos. Mato Grosso: Editora Unemat, 2007. BAUMAN, Zygmunt. Identidade. Tradução Carlos Alberto Medeiros. Rio de Janeiro: Jorge Zahar, 2005.

BRUGIONI, Elena. Literaturas africanas: estereótipo, agenciamento e romance de formação. In: BRUGIONI, Elena. Literaturas africanas comparadas: paradigmas críticos e representações em contraponto. Campinas: Unicamp, p. 113-128, 2019.

DUTRA, Robson. A infância, a guerra e a nação. In: BRUGIONI, Elena; PASSOS, Joana (Orgs.). Itinerâncias: percursos e representações da póscolonialidade. Braga: Centro de Estudos Humanísticos da Universidade do Minho, p. 229-241, 2012.

FAYE, Gaël. Meu pequeno país. Tradução de Maria de Fátima Oliva Do Coutto. São Paulo: Rádio Londres, 2018.

HALL, Stuart. A identidade em questão. In: HALL, Stuart. A identidade cultural na pós-modernidade. Tradução de Tomaz Tadeu Silva e Guacira Lopes Louro. Rio de Janeiro: DP\&A, p. 7-22, 2005.

MEIRELES, Maurício. Genocídio em Ruanda inspira autor e rapper Gäel Faye, que vem à Flip. Folha de S. Paulo, 10 maio 2019. Disponível em: https://www1.folha.uol.com.br/ilustrada/2019/05/genocidio-de-ruandainspira-autor-e-rapper-gaeel-faye-que-vem-a-flip.shtml. Acesso em: 30 out. 2020.

MEREDITH, Martin. $O$ destino da África: cinco mil anos de riquezas, ganâncias e desafios. Rio de Janeiro: Zahar, 2017. 
NUTO, João Vianney Cavalcanti. Alteridade e autoridade. Ipotesi. Juiz de Fora, v. 12, n. 2, p. 183-186, julho/dezembro de 2008.

SILVA, Tomaz Tadeu. A produção social da identidade e da diferença. In: SILVA, Tomaz Tadeu (Org.). Identidade e diferença: a perspectiva dos Estudos Culturais. Tradução de Tomaz Tadeu da Silva. São Paulo: Vozes, p. 73-102, 2005.

SILVA, Jonatan. 'Meu Pequeno País': a canção do exílio. Escotilha, 31 jul. 2019. Disponível em: http://www.aescotilha.com.br/literatura/ponto-virgula/ meu-pequeno-pais-gael-faye-resenha/. Acesso em: 02 abr. 2021. WOODWARD, Kathryn. Identidade e diferença: uma introdução teórica e conceitual. In: SILVA, Tomaz Tadeu (Org.). Identidade e diferença: a perspectiva dos Estudos Culturais. Tradução de Tomaz Tadeu da Silva. São Paulo: Vozes, p. 07-72, 2005.

\section{Leila Cristina de Melo Darin}

Doutora em Comunicação e Semiótica pela Pontifícia Universidade Católica de São Paulo (PUC-SP).

Atua na Graduação em Letras (PUC-SP) - Tradução e na Pós-graduação em Literatura e Crítica Literária. É líder do Grupo de Pesquisa em Estudos da Tradução e da Interpretação (CNPq).

Suas áreas de interesse são a Literatura Comparada, a Tradução Literária e Tradução, Língua e Cultura.

E-mail: Idarin@uol.com.br

Lattes: https://lattes.cnpq.br/2682139953614636

ORCID iD: http://orcid.org/0000-0002-3831-4342

\section{Marina Ribeiro Candido}

Mestranda com bolsa CAPES do Programa de Literatura e Crítica Literária da PUC-SP, orientanda da professora Dra. Leila Darin, desenvolvendo pesquisa sobre narrativas de infância na literatura africana.

É integrante do projeto de pesquisa Literatura e Tradução Literária: práticas do estar-entre.

E-mail: marinaribeiro.sa@gmail.com

Lattes: https://lattes.cnpq.br/3317686174676593

ORCID iD: http://orcid.org/0000-0001-9712-869X 